\title{
HUBUNGAN ANTARA STATUS NUTRISI DENGAN PRODUKSI BUAH DAN BENIH SURIAN (Toona sinensis (A. Juss.) M. Roem.) DI HUTAN RAKYAT
}

\author{
Relationship Between Nutrient Status with Fruit and Seed Productions \\ of Surian (Toona sinensis (A. Juss.) M. Roem.) on Various Agroforestry Systems
}

\author{
Agus A. Pramono ${ }^{1}$, Iskandar Z. Siregar ${ }^{2}$, Endah R. Palupi ${ }^{3}$, Cecep Kusmana ${ }^{4}$ \\ ${ }^{1}$ Balai Penelitia Teknologi Perbenihan Tanaman Hutan \\ J1. Raya Ciheuleut Po Box 105 Bogor 16001, Jawa Barat, Indonesia \\ Telp./Fax. +62-251-8327768 \\ ${ }^{2,4}$ Departemen Silvilkultur, Fakultas Kehutanan, Institut Pertanian Bogor \\ Jl. Lingkat Kampus IPB Darmaga, Bogor 16680, Jawa Barat, Indonesia \\ Telp. +62-251-8626808; Fax. +62-251-8626886 \\ ${ }^{3}$ Departemen Agronomi dan Hortikultura, Fakultas Pertanian, Institut Pertanian Bogor \\ Jl. Lingkat Kampus IPB Darmaga, Bogor 16680, Jawa Barat, Indonesia \\ Telp./Fax. +62-251-8629353
}

Email: agusastho@gmail.com ${ }^{1}$,izsiregar@gmail.com²,erpalupi@yahoo.co.id³, ckusmana@ymail.com ${ }^{4}$

Tanggal diterima: 8 Juni 2014; Tanggal direvisi: 11 November 2015; Tanggal disetujui: 13 November 2015

\begin{abstract}
On-farm trees become important sources for forest tree seeds distribution. Therefore, it is necessary to understand the effects of different land management of on-farm trees on seed production. This study was aimed to determine the nutrient status of the soil and leaf on the various types of agroforestry in small holder forests in West Java, and their effect 5 on seed production. The study was conducted in eight square plots $(50 \times 50 \mathrm{~m})$ of different planting patterns. The nutrient contents of the soil, and leaf in three samples of each plot were analyzed. The number of panicles per plant, flowers per panicle, fruits per panicle, and seeds per fruit were counted from 4 trees of each plot. The results showed that the $P, K, M g$, and organic C concentration in leaves significantly varied among agroforestry patterns. Leaf $N$ concentration was not significantly different among plots, and its availability was not a limiting factor for the seed production. Leaf Ca and Mg concentrations positively correlated with the number of panicles per plant. Ca positively affected the number of panicles per tree, while Knegatively affected the number of fruits and $P$ negatively affected the seed production. The highest yield of fruit and seed were recorded on surian monoculture plantation with intercropping or on mixed garden with intercropping.
\end{abstract}

Keywords: Flower, forest, panicles, tree, seed sources

\begin{abstract}
ABSTRAK
Pohon-pohon pada lahan milik petani telah menjadi pemasok penting dalam peredaran benih tanaman hutan. Oleh karena itu, perlu difahami pengaruh dari perbedaan pengelolaan hutan pada lahan petani terhadap produksi benih. Penelitian ini bertujuan untuk mengetahui hubungan status nutrisi tanah dan daun pada berbagai pola agroforestri di hutan rakyat di Jawa Barat, dan pengaruhnya terhadap produksi benih. Penelitian ini dilakukan pada delapan plot berbentuk bujur sangkar $(50 \times 50 \mathrm{~m})$ dari beberapa pola tanam yang berbeda. Analisis konsentrasi hara tanah dan daun dilakukan pada tiga sampel dari setiap petak. Jumlah malai per pohon, bunga per malai, buah per malai, dan benih per buah dihitung pada 4 pohon dari masing-masing plot. Hasil penelitian menunjukkan bahwa konsentrasi unsur hara $\mathrm{P}, \mathrm{K}, \mathrm{Mg}$, dan $\mathrm{C}$ pada daun bervariasi secara nyata di antara pola agroforestri. Konsentrasi $\mathrm{N}$ pada daun tidak berbeda nyata antar plot, dan ketersediaannya bukan merupakan faktor pembatas untuk produksi benih. Konsentrasi Ca berpengaruh positif terhadap jumlah malai per pohon dan jumlah bunga per malai. Konsentrasi Mg berkorelasi positif terhadap jumlah bunga per malai. $\mathrm{K}$ berpengaruh negatif terhadap produksi buah, dan $\mathrm{P}$ berpengaruh negatif terhadap produksi benih. Produksi buah dan benih tertinggi diperoleh pada tegakan surian yang ditanam monokultur dengan tumpangsari tanaman semusim atau kebun campuran yang di tumpangsarikan dengan tanaman semusim.
\end{abstract}

Kata kunci: Bunga, hutan, malai, pohon, sumber benih 


\section{PENDAHULUAN}

Dewasa ini pengembangan dan peningkatan produktivitas hutan rakyat tengah didorong oleh pemerintah. Salah satu permasalahan penting yang menjadi hambatan dalam pengembangan hutan rakyat adalah rendahnya aksesibilitas petani terhadap benih berkualitas (Van Noordwijk et al., 2003). Oleh karena itu, diperlukan upaya untuk mengembangankan sumber benih pada tegakan-tegakan di hutan rakyat, agar petani lebih mudah memperoleh benih berkualitas. Upaya ini perlu didasari dengan pemahaman tentang karakteristik lingkungan di hutan rakyat yang berpengaruh terhadap produksi benih tanaman hutan.

Keberhasilan perkembangan bunga dan perkembangan buah yang menentukan produksi benih pada tanaman hutan dipengaruhi oleh kondisi lingkungan tempat tumbuhnya. Faktor-faktor lingkungan yang diketahui berpengaruh terhadap pembungaan diantaranya adalah inten-sitas cahaya, cekaman air dan ketersediaan nutrisi (Owens, 1995), sedangkan faktor-faktor yang mempengaruhi perkembangan buah hingga masak adalah kandungan air, pasokan nutrisi, dan cuaca (Racsko et al., 2007).

Nutrisi mikro dan makro diketahui berperan penting dalam produksi buah (Jones \& Comita, 2008), sehingga pasokan nutrisi yang seimbang selalu diperlukan untuk mewujudkan produksi buah yang optimal (Renison et al., 2004). Pohon induk yang mengalami kekurangan unsur hara selama perkembangan benihnya dapat mengakibatkan benih berkembang tanpa gizi yang seimbang, sehingga benih akan kekurangan unsurunsur hara ensensial tertentu (Kozlowski, 1971; Kuswanto, 1996). Konsentrasi N, P, K, Ca, Mg, $\mathrm{Fe}, \mathrm{Mn}$ dan $\mathrm{Zn}$ dalam daun berkorelasi dengan produksi buah pohon carob (Ceratonia siliqua L.), pada model estimasi yang terbaik diindikasikan bahwa $92 \%$ variasi produksi buah carob berkorelasi dengan N, P, K, Mn dan Fe dalam daun (Correia et al., 2002).

Pola pengelolaan lahan dapat meningkatkan kualitas nutrisi yang mendukung produksi benih. Pada tanaman M. zapota, peningkatkan ketersediaan air dan hara berpengaruh positif pada fase pematangan buah sehingga meningkatkan produksi dan berat buah (Peba \& Tabla, 2007). Pengelolan tegakan dalam bentuk tumpangsari dapat memperbaiki status nutrisi tanaman, pertumbuhan pohon dan berpotensi mempercepat produksi buah (Chifflot et al., 2006). Perbedaan pengelolaan lahan di bawah tegakan pada sistem agrosilvopastura berpengaruh pada kondisi mikroklimat, nutrisi dan produksi buah acorn (Marcos et al., 2007). Sebaliknya, eksploitasi lahan yang menyebabkan tapak terdegradasi berat dapat menyebabkan penurunan produksi, seperti penurunan ukuran buah, serta berat dan ukuran benih, seperti pada Pinus pinea (Ganatsas et al., 2008).

Pohon surian (Toona sinensis (A. Juss.) M. Roem.) banyak ditanaman di hutan rakyat dalam berbagai pola tanam (Pramono, 2009). Di Jawa Barat menurut Sardjono et al. (2003) pola pengelolaan yang berkembang di hutan rakyat adalah pohon dengan tanaman semusim (plantation crop combination), kebun pekarangan (homegardens), kombinasi tanaman keras (mixtures of plantation crops) atau kebun campuran, silvopastura, dan kebun hutan (forest-gardens) atau talun. Informasi tentang pengaruh perbedaan status unsur hara makro dan mikro tanah pada berbagai pola pengeloalan tersebut terhadap status nutrisi daun dan produksi benih surian belum pernah terlaporkan. Informasi ini sangat diperlukan untuk menjawab pertanyaan apakah status nutrisi menjadi kendala dalam produksi benih surian pada lahan-lahan di hutan rakyat, serta untuk menentukan tindakan pemupukan yang tepat dalam mengatasi kendala rendanya produksi benih pada suatu sumber benih surian. Berbagai penelitian telah menunjukkan bahwa peningkatan kandungan nutrisi melalui pemupukan dapat digunakan untuk meningkatkan produksi benih, dan untuk mempercepat proses pembuahan sehingga pohon akan berbuah pada umur muda (Gray \& Garrett, 1999).

Penelitian ini bertujuan untuk mengetahui status nutrisi tanah dan daun surian (Toona sinensis) pada beberapa tegakan di hutan rakyat di Jawa Barat serta pengaruhnya terhadap produksi benih.

\section{METODOLOGI}

\section{A. Lokasi dan Waktu Penelitian}

Penelitian dilakukan di hutan rakyat di Kabupaten Sumedang Provinsi Jawa Barat. Wilayah ini memiliki curah hujan $2.174 \mathrm{~mm} /$ tahun. Lokasi penelitian berada di Desa Sukajadi, Kecamatan Wado, dan Desa Padasari, Kecamatan Cimalaka. Kedua desa tersebut berada di Kabupaten Sumedang. Penelitian dilakukan dari Bulan Februari 2012 hingga Agustus 2013. 


\section{B. Bahan dan Alat}

Bahan penelitian berupa tegakan surian di hutan rakyat dengan pola pengelolaan yang berbeda. Dari kedua desa tersebut dibuat 8 plot yang mewakili 8 pola tanam yang berbeda dan berfungsi sebagai perlakuan perbedaan status nutrisi. Plot berbentuk bujursangkar berukuran 50 x 50 m, yaitu 5 plot di Desa Sukajadi (S1, S2, S3, S4, dan S5), dan 3 plot di Desa Padasari (P1, P2, dan P3).

Kelima plot penelitian yang berada di Desa Sukajadi terletak pada $06^{\circ} 59^{\prime} \mathrm{LS}, 108^{\circ} 07-$ $108^{\circ} 06^{\prime} \mathrm{BT}$, berada pada ketinggian tempat 850 $860 \mathrm{~m}$ dpl, dengan kondisi lahan landai, miring dan bergelombang. Tiga plot penelitian yang berada di Desa Padasari, Kecamatan Cimalaka terletak pada $06^{\circ} 46^{\prime} \mathrm{LS}, 107^{\circ} 55^{\prime} \mathrm{BT}$, berada pada ketinggian tempat 685-700 $\mathrm{m}$ dpl dengan topografi datar.

Plot S1, S2 dan S3 merupakan tegakan yang didominasi oleh surian dan hampir monokultur dengan kerapatan tegakan yang berbeda, pada lantai bawah digunakan untuk tumpangsari pada musim penghujan. Pada ketiga plot ini persentase surian (proporsi jumlah pohon surian dibandingkan dengan jumlah seluruh pohon pada plot) lebih tinggi dibandingkan dengan plot lainnya. Plot S4 dan S5 berada pada kebun campuran yang didominasi oleh cengkih, surian dan mahoni. Plot P1 berada pada hutan campuran rapat yang didominasi oleh mahoni dan pada beberapa bagian lahan digunakan untuk tumpangsari tanaman pertanian, dan sebagian lainnya digunakan untuk tumpangsari dengan kopi dan vanili yang ditanam tidak beraturan. Plot P2 merupakan tegakan pekarangan yang didominasi oleh surian. Plot P3 merupakan hutan campuran yang didominasi mahoni dan surian tanpa sistem tumpangsari. Kondisi tegakan, secara lebih lengkap ditampilkan pada Tabel 1.

\section{Metode Analisis}

\section{Analisis kimiawai tanah dan daun}

Untuk analisis fisik tanah, diambil 3 sampel untuk setiap plot dengan menggunakan ring. Untuk analisis kimia diambil dengan menggunakan sekop kecil kemudian dimasukkan ke dalam kantong plastik, diikat dan dibawa ke laboratorium. Sampel tanah diambil di bawah tajuk pada posisi $50 \mathrm{~cm}$ dari batang pohon sebanyak 0,5-1 kg dengan kedalaman 0-40 $\mathrm{cm}$ (Chifflot et

Tabel(Table) 1. Kondisi tegakan agroforestri yang diamati (The condition of observed agroforestry stands)

\begin{tabular}{|c|c|c|c|c|c|c|c|}
\hline $\begin{array}{l}\text { Perlakuan } \\
\text { (Treatments) }\end{array}$ & $\begin{array}{l}\text { Jumlah } \\
\text { Spesies } \\
\text { pohon } \\
\text { (Number of } \\
\text { trees species) }\end{array}$ & $\begin{array}{l}\text { Tanaman } \\
\text { dominan } \\
\text { (Dominan } \\
\text { species) }\end{array}$ & $\begin{array}{l}\text { Jumlah pohon } \\
\text { surian dalam } \\
\text { plot } \\
\text { (Number of } \\
\text { surian trees) }\end{array}$ & $\begin{array}{l}\text { Persen pohon } \\
\text { surian } \\
\text { (Percentage of } \\
\text { surian trees) } \\
\quad(\%)\end{array}$ & $\begin{array}{c}\text { Jumlah Semua } \\
\text { pohon/ha } \\
\text { Number of all } \\
\text { trees/ha }(\text { Number of } \\
\text { trees } / \text { ha })\end{array}$ & $\begin{array}{c}\text { Rataan } \\
\text { diameter } \\
\text { batang surian } \\
\text { (Average of } \\
\text { stem dimeterof } \\
\text { surian) }(\mathrm{cm})\end{array}$ & $\begin{array}{c}\text { Sistem agroforestri } \\
\text { (Agroforestry systems) }\end{array}$ \\
\hline S1 & 3 & Surian & 27 & 84 & 128 & $24,5 \pm 4,5$ & $\begin{array}{l}\text { Pohon dengan tanaman } \\
\text { semusim (Plantation Crop } \\
\text { Combination), }\end{array}$ \\
\hline S2 & 4 & Surian & 54 & 86 & 252 & $22,6 \pm 4,5$ & $\begin{array}{l}\text { Pohon dengan tanaman } \\
\text { semusim (Plantation Crop } \\
\text { Combination), }\end{array}$ \\
\hline S3 & 4 & Surian & 62 & 94 & 264 & $23,3 \pm 3,4$ & $\begin{array}{l}\text { Pohon dengan tanaman } \\
\text { semusim (Plantation Crop } \\
\text { Combination), } \\
\text { Kebun campuran }\end{array}$ \\
\hline S4 & 11 & Surian & 33 & 38 & 348 & $18,7 \pm 4,6$ & $\begin{array}{l}\text { (Mixed garden, } \\
\text { intercropping) }\end{array}$ \\
\hline S5 & 9 & $\begin{array}{l}\text { cengkih, } \\
\text { surian }\end{array}$ & 19 & 23 & 324 & $20,7 \pm 5,7$ & $\begin{array}{l}\text { Kebun campuran } \\
\text { (Mixed garden) }\end{array}$ \\
\hline P1 & 9 & $\begin{array}{l}\text { mahoni, } \\
\text { surian }\end{array}$ & 27 & 19 & 553 & $18,6 \pm 4,3$ & $\begin{array}{l}\text { Kebun hutan, sebagian } \\
\text { tumpangsari } \\
\text { (Forest garden, partly } \\
\text { intercropping) }\end{array}$ \\
\hline $\mathrm{P} 2$ & 14 & Surian & 30 & 34 & 356 & $28,9 \pm 8,4$ & $\begin{array}{l}\text { Kebun pekarangan } \\
\text { (Home-garden) }\end{array}$ \\
\hline P3 & 9 & $\begin{array}{l}\text { mahoni, } \\
\text { surian }\end{array}$ & 37 & 23 & 633 & $24,5 \pm 5,1$ & $\begin{array}{l}\text { Kebun hutan } \\
\text { (Forest garden) }\end{array}$ \\
\hline
\end{tabular}

Sumber (Source): Diolah dari data lapang (Compiled and analyzed from field data) 
al., 2006) dari 3 titik secara acak. Analisis tanah dilakukan di laboratorium SEAMEO BIOTROP Bogor. Pengukuran $\mathrm{pH}$ menggunakan metode SNI 03-6787-2002, C organik dengan metode SNI 13-4720-1998 (Walkey \& Black), N total dengan metode SNI 13-4721-1998 (Kjeldahl), P tersedia dengan metode SL-MU-TT-05 (Bray $\mathrm{I} / \mathrm{II})$, pengukuran $\mathrm{Ca}, \mathrm{Mg}$, K, KTK menggunakan metode SL-MU-TT-07a-c (Ekstrak Penyangga NH4OAc 1,0 N pH 7,0), Al dengan metode SLMU-TT-09 (Ekstrak KCl $1 \mathrm{~N}$ ), tekstur 3 fraksi menggunakan metode SL-MU-TT-10 (Hidrometer). Untuk analisis kimia daun, diambil 3 pohon contoh pada setiap plot. Analisis kimiawi daun meliputi konsentrasi N, P, K, Ca, Mg, Fa Mn, C organik dan $\mathrm{Na}$.

\section{Produksi bunga, buah dan benih}

Pengamatan produksi benih dilakukan pada 4 pohon dalam setiap plot dengan parameter meliputi jumlah malai per pohon, bunga per malai, buah per malai dan benih per buah. Untuk pengamatan jumlah bunga per malai dan jumlah buah per malai dilakukan pengunduhan 4 malai setiap pohon contoh dan setiap malai dihitung jumlah buahnya. Dari setiap sampel malai diambil buah sebanyak 4 x 10 butir untuk pengukuran dimensi buah dan penghitungan jumlah benih. Setiap buah diukur panjang, diameter, jumlah benih kosong, dan benih bernas.

\section{Analisis Data}

Ada tidaknya kaitan antara varibel-variabel nutrisi daun terhadap variabel produksi benih dianalisis dengan menggunakan korelasi Pearson. ANOVA digunakan untuk menganalisis perbedaan status nutrisi tanah, nutrisi daun, jumlah bunga, jumlah buah, jumlah benih dan ukuran buah T. sinensis antar plot penelitian. Data dikumpulkan dari dari 8 plot dengan 4 ulangan. Untuk ukuran buah dan jumlah benih, masingmasing ulangan merupakan rataan dari 3 malai dan 10 sampel buah. Selanjutnya data dianalisis dengan uji jarak berganda Duncan.

\section{HASIL DAN PEMBAHASAN}

\section{A. Hasil}

\section{Konsentrasi hara tanah}

Hasil analisis kimia tanah pada plot yang diamati ditampilkan pada Tabel 2. Hasilnya menunjukkan bahwa secara umum $\mathrm{pH} \mathrm{H}_{2} \mathrm{O}$ di lokasi penelitian adalah asam atau agak asam antara 4,73 dan 6,23. Di plot S1, S2, S3, S4 dan S5 pH tanahnya rata-rata berkisar 4,73-5,33, pada tingkat ini menururt Balai Penelitian Tanah Badan Penelitian dan Pengembangan Pertanian Departemen Pertanian (2005) tergolong masam, dan di plot P1, P2, P3 termasuk agak asam dengan $\mathrm{pH}$ 6,20-6,23. Parameter lainnya yaitu C, N, C/N, P, $\mathrm{Ca}, \mathrm{Mg}, \mathrm{K}, \mathrm{KTK}$, kadar pasir, debu dan liat berbeda secara nyata antar plot. Semua unsur kesuburan tanah berpengaruh nyata.

Plot S1, S2 dan S3 memiliki kesuburan tanah yang sangat mirip yang ditunjukkan dari hasil analisis variansi bahwa konsentrasi $\mathrm{C}, \mathrm{N}, \mathrm{P}, \mathrm{Ca}$, $\mathrm{Mg}, \mathrm{KTK}$, pasir, debu dan liat di antara ketiga plot tersebut tidak berbeda nyata. Berdasarkan pH tanah, secara umum plot-plot yang berada di Desa Sukajadi (S1, S2, S3 , S4 dan S5) secara nyata lebih asam dibandingkan plot-plot di Desa Padasari (P1, P2 dan P3). Diantara kedelapan plot penelitian plot S5 paling asam. Plot ini secara

Tabel(Table) 2. Rata-rata konsentrasi unsur hara dalam tanah di plot penelitian (The average concentration of soil nutrient in research plots)

\begin{tabular}{|c|c|c|c|c|c|c|c|c|c|c|c|c|}
\hline Perlakuan & $\begin{array}{c}\mathrm{pH} \\
\mathrm{H} 2 \mathrm{O}\end{array}$ & $\begin{array}{c}\text { C org } \\
(\%)\end{array}$ & $\begin{array}{c}\mathrm{N} \text { tot } \\
(\%)\end{array}$ & $\begin{array}{c}\text { Rasio } \\
\mathrm{C} / \mathrm{N}\end{array}$ & $\begin{array}{c}\mathrm{P} \\
\text { tersedia } \\
(\mathrm{ppm})\end{array}$ & $\begin{array}{c}\begin{array}{c}\mathrm{Ca} \\
(\mathrm{me} /\end{array} \\
100 \mathrm{~g})\end{array}$ & $\begin{array}{c}\begin{array}{l}\mathrm{Mg} \\
(\mathrm{me} /\end{array} \\
100 \mathrm{~g})\end{array}$ & $\begin{array}{c}\mathrm{K} \\
(\mathrm{me} \\
/ 100 \mathrm{~g})\end{array}$ & KTK & Pasir & Debu & Liat \\
\hline S1 & $5,17 \mathrm{ab}$ & 1,49 a & $0,16 \mathrm{ab}$ & $9,13 \mathrm{ab}$ & 3,43 a & 2,69 a & $1,20 \mathrm{~A}$ & $0,48 \mathrm{ab}$ & 10,29 a & $44,67 \mathrm{~b}$ & $47,73 \mathrm{C}$ & $44,67 \mathrm{~b}$ \\
\hline S2 & $5,17 \mathrm{ab}$ & 1,45 a & 0,15 a & $9,67 \mathrm{ab}$ & 2,46 a & 2,46 a & $1,29 \mathrm{~A}$ & $1,40 \mathrm{c}$ & $10,65 \mathrm{a}$ & $43,90 \mathrm{~b}$ & $47,43 \mathrm{C}$ & $43,90 \mathrm{~b}$ \\
\hline S3 & $5,23 \mathrm{~b}$ & $2,20 \mathrm{ab}$ & $0,20 a b c$ & $10,97 \mathrm{~b}$ & $4,12 \mathrm{a}$ & 3,11 a & $1,68 \mathrm{~A}$ & $0,90 \mathrm{bc}$ & $12,89 \mathrm{a}$ & $44,20 \mathrm{~b}$ & $48,20 \mathrm{C}$ & $44,20 \mathrm{~b}$ \\
\hline S4 & $5,33 \mathrm{~b}$ & $2,47 \mathrm{~b}$ & $0,27 \mathrm{~cd}$ & $9,13 \mathrm{ab}$ & 3,40 a & $4,75 \mathrm{ab}$ & $2,90 \mathrm{~B}$ & $0,20 \mathrm{a}$ & $14,12 \mathrm{ab}$ & $42,70 \mathrm{~b}$ & $48,33 \mathrm{C}$ & $42,70 \mathrm{~b}$ \\
\hline S5 & 4,73 a & $1,62 \mathrm{ab}$ & $0,16 \mathrm{ab}$ & $9,87 \mathrm{ab}$ & $4,32 \mathrm{a}$ & $2,24 \mathrm{a}$ & $1,28 \mathrm{~A}$ & $0,17 \mathrm{a}$ & $11,00 \mathrm{a}$ & $41,93 \mathrm{~b}$ & $50,27 \mathrm{C}$ & $41,93 \mathrm{~b}$ \\
\hline P1 & $6,20 \mathrm{c}$ & $5,08 \mathrm{c}$ & $0,30 \mathrm{~d}$ & $16,53 \mathrm{c}$ & 27,40 a & $6,72 \mathrm{~b}$ & $1,05 \mathrm{~A}$ & $1,47 \mathrm{c}$ & $17,14 \mathrm{bc}$ & $14,60 \mathrm{a}$ & $23,30 \mathrm{~A}$ & $14,60 \mathrm{a}$ \\
\hline $\mathrm{P} 2$ & $6,23 \mathrm{c}$ & $2,16 \mathrm{ab}$ & $0,27 \mathrm{~cd}$ & 8,10 a & $156,69 \mathrm{~b}$ & $13,95 \mathrm{~d}$ & $1,59 \mathrm{~A}$ & $1,29 \mathrm{c}$ & $23,68 \mathrm{~d}$ & $38,23 \mathrm{~b}$ & $37,33 \mathrm{~B}$ & $38,23 \mathrm{~b}$ \\
\hline P3 & $6,23 \mathrm{c}$ & $4,62 \mathrm{c}$ & $0,24 \mathrm{bcd}$ & $19,63 \mathrm{~d}$ & 11,43 a & $9,88 \mathrm{c}$ & $1,28 \mathrm{~A}$ & $2,72 \mathrm{~d}$ & $20,19 \mathrm{~cd}$ & 16,37 a & $29,33 \mathrm{Ab}$ & $16,37 \mathrm{a}$ \\
\hline
\end{tabular}

Sumber (Source): Diolah dari data lapang (Compiled and analyzed from field data)

Keterangan(Remarks): Rataan yang diikuti oleh huruf sama pada kolom sama menunjukkan tidak ada perbedaan nyata pada tingat kepercayaan 95\% (Means followed by the same latter at the same column are not significantly different at $95 \%$ confidence level) 
Tabel (Table) 3. ANOVA status nutrisi daun T. sinensis antar plot penelitian (ANOVA of T. sinensis leaf nutrition among research plots)

\begin{tabular}{lll}
\hline \multicolumn{1}{c}{ Parameter } & \multicolumn{1}{c}{ F } & \multicolumn{1}{c}{ Sig. } \\
\hline Nitrogen (N) & 2,129 & 0,100 \\
Phosphorus (P) & 3,184 & $0,026^{*}$ \\
Potassium (K) & 6,819 & $0,001^{* *}$ \\
Calcium ( Ca) & 1,840 & 0,148 \\
Magnesium (Mg) & 4,492 & $0,006^{* *}$ \\
Iron (Fe) & 2,446 & 0,066 \\
Manganese (Mn) & 0,715 & 0,661 \\
Organic Carbon (Corg) & 6,113 & $0,001^{* *}$ \\
$\mathrm{Na}$ & 0,753 & 0,633 \\
\hline
\end{tabular}

Sumber (Source): Diolah dari data lapang (Compiled and analyzed from field data)

nyata lebih asam dibanding plot S3, S4, P1, P2 dan $\mathrm{P} 3$, namun tidak berbeda nyata dengan S1 dan S2. Plot P1 dan P2 memiliki kemiripan dalam tingginya status nutrisi tanahnya yang meliputi tingginya konsentrasi $\mathrm{C}, \mathrm{N}, \mathrm{Ca}, \mathrm{K}$ dan kapasitas tukar kationnya. Semua plot yang berada di Desa Sukajadi memiliki konsentrasi liat dan debu yang tidak berbeda nyata dan secara nyata lebih tinggi jika dibandingkan dengan plot-plot yang berlokasi di Desa Padasari.

\section{Konsentrasi unsur hara pada daun}

Rata-rata konsentrasi unsur hara daun pada setiap plot ditampilkan pada Tabel 4. Unsur hara daun yang berbeda nyata antar lokasi adalah konsentrasi $\mathrm{P}, \mathrm{K}, \mathrm{Mg}$ dan $\mathrm{C}$ organik, sedangkan unsur lain tidak berbeda nyata. Konsentrasi $\mathrm{P}$ dalam daun surian sangat bervariasi antara 0,13 sampai 0,22. Konsentrasi $\mathrm{P}$ tertinggi dijumpai pada blok Padasari 2. Konsentrasi anasir K di dalam daun bervariasi antara $0,78-1,80$, dan berdasarkana ANOVA konsentrasi K berbeda nyata antar plot penelitian. Konsentrasi K pada plotplot di Padasari (P1, P2 dan P3) lebih tinggi daripada konsentrasi K pada plot-plot di desa Sukajadi (S1,S2, S3, S4, S5). Selain K konsentrasi unsur hara yang berbeda nyata antar plot penelitian adalah P, Mg, dan C organik (Tabel 3).

\section{Korelasi antara Nutrisi Tanah dengan Nutrisi Daun}

Hasil analisis korelasi Pearson ditemukan bahwa kandungan unsur hara pada tanah tidak menunjukkan korelasi yang nyata dengan kandungan unsur hara bersangkutan di dalam daun. Konsentrasi beberapa unsur hara pada tanah berkorelasi dengan konsentrasi berapa unsur hara lain pada daun. Parameter kesuburan tanah yang berpengaruh terhadap kandungan $\mathrm{P}$ dan $\mathrm{K}$ tanah

Tabel (Table) 4. Rata-rata konsentrasi nutrisi daun surian (T. sinensis) antar tegakan sampel (The average concentration of surian (T. sinensis) leaf nutrition of sample stands)

\begin{tabular}{cccccccccc}
\hline Lokasi & $\begin{array}{c}\mathrm{N} \\
(\%)\end{array}$ & $\begin{array}{c}\mathrm{P} \\
(\%)\end{array}$ & $\begin{array}{c}\mathrm{K} \\
(\%)\end{array}$ & $\begin{array}{c}\mathrm{Ca} \\
(\%)\end{array}$ & $\begin{array}{c}\mathrm{Mg} \\
(\%)\end{array}$ & $\begin{array}{c}\mathrm{Fe} \\
(\mathrm{ppm})\end{array}$ & $\begin{array}{c}\mathrm{Mn} \\
(\mathrm{ppm})\end{array}$ & $\begin{array}{c}\mathrm{C} \text { Org } \\
(\%)\end{array}$ & $\begin{array}{c}\mathrm{Na} \\
(\%)\end{array}$ \\
\hline S1 & $3,13 \mathrm{a}$ & $0,13 \mathrm{a}$ & $0,79 \mathrm{abc}$ & $1,16 \mathrm{a}$ & $0,14 \mathrm{ab}$ & $269,88 \mathrm{a}$ & $30,99 \mathrm{a}$ & $47,26 \mathrm{ab}$ & $0,01 \mathrm{a}$ \\
$\mathrm{S} 2$ & $2,75 \mathrm{a}$ & $0,13 \mathrm{a}$ & $0,78 \mathrm{ab}$ & $0,92 \mathrm{a}$ & $0,10 \mathrm{a}$ & $231,97 \mathrm{a}$ & $31,16 \mathrm{a}$ & $51,43 \mathrm{~b}$ & $0,01 \mathrm{a}$ \\
$\mathrm{S} 3$ & $2,61 \mathrm{a}$ & $0,14 \mathrm{ab}$ & $0,98 \mathrm{abc}$ & $0,71 \mathrm{a}$ & $0,11 \mathrm{a}$ & $203,50 \mathrm{a}$ & $31,16 \mathrm{a}$ & $51,43 \mathrm{~b}$ & $0,01 \mathrm{a}$ \\
S4 & $3,15 \mathrm{a}$ & $0,14 \mathrm{ab}$ & $0,58 \mathrm{a}$ & $0,93 \mathrm{a}$ & $0,13 \mathrm{ab}$ & $163,47 \mathrm{a}$ & $22,35 \mathrm{a}$ & $49,12 \mathrm{ab}$ & $0,02 \mathrm{a}$ \\
S5 & 2,86 a & $0,16 \mathrm{abc}$ & $1,10 \mathrm{abc}$ & $1,11 \mathrm{a}$ & $0,16 \mathrm{~b}$ & $212,92 \mathrm{a}$ & $30,92 \mathrm{a}$ & $48,53 \mathrm{ab}$ & $0,01 \mathrm{a}$ \\
P1 & 2,93 a & $0,19 \mathrm{bc}$ & $1,31 \mathrm{bcd}$ & $0,81 \mathrm{a}$ & $0,13 \mathrm{ab}$ & $180,09 \mathrm{a}$ & $29,74 \mathrm{a}$ & $46,18 \mathrm{a}$ & $0,01 \mathrm{a}$ \\
P2 & 3,12 a & $0,22 \mathrm{c}$ & $1,80 \mathrm{~d}$ & $1,33 \mathrm{a}$ & $0,16 \mathrm{~b}$ & $167,94 \mathrm{a}$ & $31,72 \mathrm{a}$ & $45,12 \mathrm{a}$ & $0,03 \mathrm{a}$ \\
P3 & 2,37 a & $0,17 \mathrm{abc}$ & $1,50 \mathrm{~cd}$ & $1,05 \mathrm{a}$ & $0,14 \mathrm{ab}$ & $218,08 \mathrm{a}$ & $27,89 \mathrm{a}$ & $47,08 \mathrm{a}$ & $0,01 \mathrm{a}$ \\
\hline
\end{tabular}

Sumber (Source): Diolah dari data lapang (Compiled and analyzed from field data)

Keterangan(Remarks): Rataan yang diikuti oleh huruf sama pada kolom sama menunjukkan tidak ada perbedaan nyata pada tingat kepercayaan $95 \%$. (Means followed by the same latter at the same column are not significantly different at $95 \%$ confidence level) 
adalah pH tanah, Kapasitas Tukar Kation (KTK) dan kandungan anasir hara $\mathrm{Ca}$ (Tabel 5). Konsentrasi $\mathrm{P}$ dan $\mathrm{K}$ pada daun meningkat sejalan dengan meningkatnya $\mathrm{pH}, \mathrm{KTK}$ dan konsentrasi $\mathrm{Ca}$ daun. Konsentrasi $\mathrm{K}$ pada daun juga sejalan dengan meningkatnya $\mathrm{P}$ dan berlawanan dengan meningkatnya konsentrasi debu di dalam tanah. Konsentrasi C organik pada daun berkorelasi negatif dengan konsentrasi $\mathrm{Ca}$ tanah, konsentrasi $\mathrm{Fe}$ pada daun berkorelasi negatif dengan $\mathrm{N}$ tanah, konsentrasi Mn pada dau berkorelasi negatif dengan konsentrasi $\mathrm{Mg}$ tanah, dan konsentrasi $\mathrm{Na}$ pada daun berkorelasi dengan konsentrasi $\mathrm{Na}$ tanah.

\section{Produksi bunga, buah dan benih}

Berdasarkan hasil ANOVA terhadap produksi bunga, buah dan benih diketahui bahwa terdapat perbedaan yang nyata antar plot dalam hal variasi buah per malai, panjang buah, diameter buah, jumlah benih per buah dan daya kecambah benih, tetapi jumlah malai per pohon, rasio diameter dengan panjang buah, dan jumlah ovul per bunga tidak berbeda secara nyata antar plot (Tabel 7).

Rata-rata jumlah malai tertinggi dijumpai pada plot P2. Pohon surian pada plot ini menghasilkan malai bervariasi dari 40 malai hingga 165 malai per pohon dengan rata-rata 73,75 malai per pohon. Produksi malai terendah dijumpai pada Plot S5 yang manghasilkan rata-rata 22,75 malai per pohon. Produksi malai ini tidak berbeda nyata antar plot pengamatan.

Jumlah buah per malai berbeda nyata di antara plot. Jumlah buah paling tinggi ditemui pada plot S4 yaitu 359,8+108,4 buah per malai. Jumlah ini secara statistik tidak berbeda nyata dengan plot S1, S2 dan S5, namun secara nyata lebih tinggi dari pada jumlah buah pada plot S3, P1, P2 dan P3.

Jumlah benih per buah antara plot S1, S2, S3, S4, P1, P2 dan P3 tidak berbeda nyata. Jumlah benih paling sedikit dijumpai pada pada P2 $(10,547 \pm 1,78)$. Jumlah ini tidak berbeda nyata dengan jumlah benih pada plot S3 dan P3.

Tabel(Table) 5. Hasil analisis korelasi antara status nutrisi tanah dengan nutrisi daun (The result of correlation analysis between soil nutrition and leafnutrition)

\begin{tabular}{|c|c|c|c|c|c|c|c|c|c|c|}
\hline \multirow{2}{*}{$\begin{array}{c}\text { Nutrisi } \\
\text { tanah } \\
\text { (Soil } \\
\text { nutrition) }\end{array}$} & & \multicolumn{9}{|c|}{ Nurisi daun (Leaf nutritionI) } \\
\hline & & $\begin{array}{c}\mathrm{N} \\
(\%)\end{array}$ & $\begin{array}{c}\mathrm{P} \\
(\%)\end{array}$ & $\begin{array}{c}\mathrm{K} \\
(\%)\end{array}$ & $\begin{array}{l}\mathrm{Ca} \\
(\%)\end{array}$ & $\begin{array}{l}\mathrm{Mg} \\
(\%)\end{array}$ & $\begin{array}{c}\mathrm{Fe} \\
(\mathrm{ppm})\end{array}$ & $\begin{array}{c}\mathrm{Mn} \\
(\mathrm{ppm})\end{array}$ & $\begin{array}{c}\mathrm{C} \\
(\%)\end{array}$ & $\begin{array}{l}\mathrm{Na} \\
(\%)\end{array}$ \\
\hline \multirow[t]{2}{*}{$\mathrm{pH} \mathrm{H}_{2} \mathrm{O}$} & Kor. & $-0,127$ & $0,746^{*}$ & $0,755^{*}$ & 0,151 & 0.202 & $-0,440$ & $-0,061$ & $-0,688$ & 0,297 \\
\hline & Sig. & 0,764 & 0,033 & 0,030 & 0,721 & 0.632 & 0,276 & 0,885 & 0,059 & 0,475 \\
\hline \multirow[t]{2}{*}{$\mathrm{N}$} & Kor. & 0,209 & 0,653 & 0,422 & $-0,090$ & 0.195 & $-0,787^{*}$ & $-0,448$ & $-0,567$ & 0,425 \\
\hline & Sig. & 0,620 & 0,079 & 0,298 & 0,833 & 0.644 & 0,020 & 0,266 & 0,142 & 0,294 \\
\hline \multirow[t]{2}{*}{$\mathrm{P}$} & Kor. & 0,359 & 0,825 & $0,755^{*}$ & 0,617 & 0.488 & $-0,480$ & 0,288 & $-0,630$ & $0,844 *$ \\
\hline & Sig. & 0,383 & 0,012 & 0,030 & 0,103 & 0.220 & 0,229 & 0,489 & 0,094 & 0,008 \\
\hline \multirow[t]{2}{*}{ K } & Kor. & $-0,756^{*}$ & 0,483 & 0,776 & $-0,080$ & -0.108 & 0,022 & 0,042 & $-0,329$ & $-0,640$ \\
\hline & Sig. & 0,049 & 0,272 & 0,040 & 0,865 & 0.817 & 0,962 & 0,928 & 0,471 & 0,122 \\
\hline \multirow[t]{2}{*}{$\mathrm{C}$} & Kor. & $-0,380$ & 0,452 & 0,443 & $-0,287$ & 0.024 & $-0,332$ & $-0,262$ & $-0,446$ & $-0,261$ \\
\hline & Sig. & 0,354 & 0,261 & 0,271 & 0,491 & 0.955 & 0,421 & 0,531 & 0,268 & 0,532 \\
\hline \multirow[t]{2}{*}{$\mathrm{C} / \mathrm{N}$} & Kor. & 0,680 & 0,229 & 0,378 & $-0,295$ & -0.051 & $-0,012$ & $-0,137$ & $-0,255$ & $-0,570$ \\
\hline & Sig. & 0,063 & 0,585 & 0,356 & 0,479 & 0,905 & 0,977 & 0,747 & 0,542 & 0,140 \\
\hline \multirow[t]{2}{*}{$\mathrm{Ca}$} & Kor. & 0,018 & $0,854 *$ & $0,858^{*}$ & 0,502 & 0,487 & $-0,515$ & $-0,008$ & $-0,731^{*}$ & 0,584 \\
\hline & Sig. & 0,967 & 0,007 & 0,006 & 0,205 & 0,221 & 0,191 & 0,986 & 0,040 & 0,128 \\
\hline \multirow[t]{2}{*}{$\mathrm{Mg}$} & Kor. & 0,352 & $-0,231$ & $-0,449$ & $-0,143$ & $-0,027$ & $-0,513$ & $-0,786^{*}$ & 0,270 & 0,407 \\
\hline & Sig. & 0,392 & 0,582 & 0,265 & 0,735 & 0,949 & 0,193 & 0,021 & 0,519 & 0,317 \\
\hline \multirow[t]{2}{*}{ KTK } & Kor. & $-0,070$ & $0,852 *$ & $0,861 *$ & 0,379 & 0,406 & $-0,561$ & $-0,025$ & $-0,680$ & 0,520 \\
\hline & Sig. & 0,870 & 0,007 & 0,006 & 0,355 & 0,319 & 0,148 & 0,954 & 0,064 & 0,186 \\
\hline \multirow[t]{2}{*}{ Pasir } & Kor. & $-0,338$ & 0,594 & 0,615 & $-0,085$ & 0,128 & $-0,267$ & $-0,062$ & $-0,592$ & $-0,169$ \\
\hline & Sig. & 0,413 & 0,121 & 0,105 & 0,841 & 0,763 & 0,523 & 0,884 & 0,122 & 0,690 \\
\hline \multirow[t]{2}{*}{ Debu } & Kor. & 0,245 & 0,665 & $-0,669^{*}$ & 0,032 & $-0,128$ & 0,308 & $-0,001$ & 0,645 & 0,034 \\
\hline & Sig. & 0,559 & 0,072 & 0,070 & 0,941 & 0,762 & 0,458 & 0,998 & 0,084 & 0,937 \\
\hline \multirow[t]{2}{*}{ Liat } & Kor. & 0,405 & $-0,523$ & $-0,557$ & 0,127 & $-0,125$ & 0,229 & 0,113 & 0,536 & 0,274 \\
\hline & Sig. & 0,319 & 0,183 & 0,151 & 0,764 & 0,768 & 0,585 & 0,790 & 0,171 & 0,511 \\
\hline
\end{tabular}

Sumber (Source): Diolah dari data lapang (Compiled and analyzed from field data)

Keterangan $\left(\right.$ Remarks): ${ }^{*}=$ Ada perbedaan nyata antar plot pada tingkat 0,$05 ;$ Kor $=$ Koefisien korelasi; Sig $=$ Nilai $p(*=$ There are different significantly among plot at the 0.05 level; Kor $=$ Corellation coefficient; Sig $=p$-Value). 

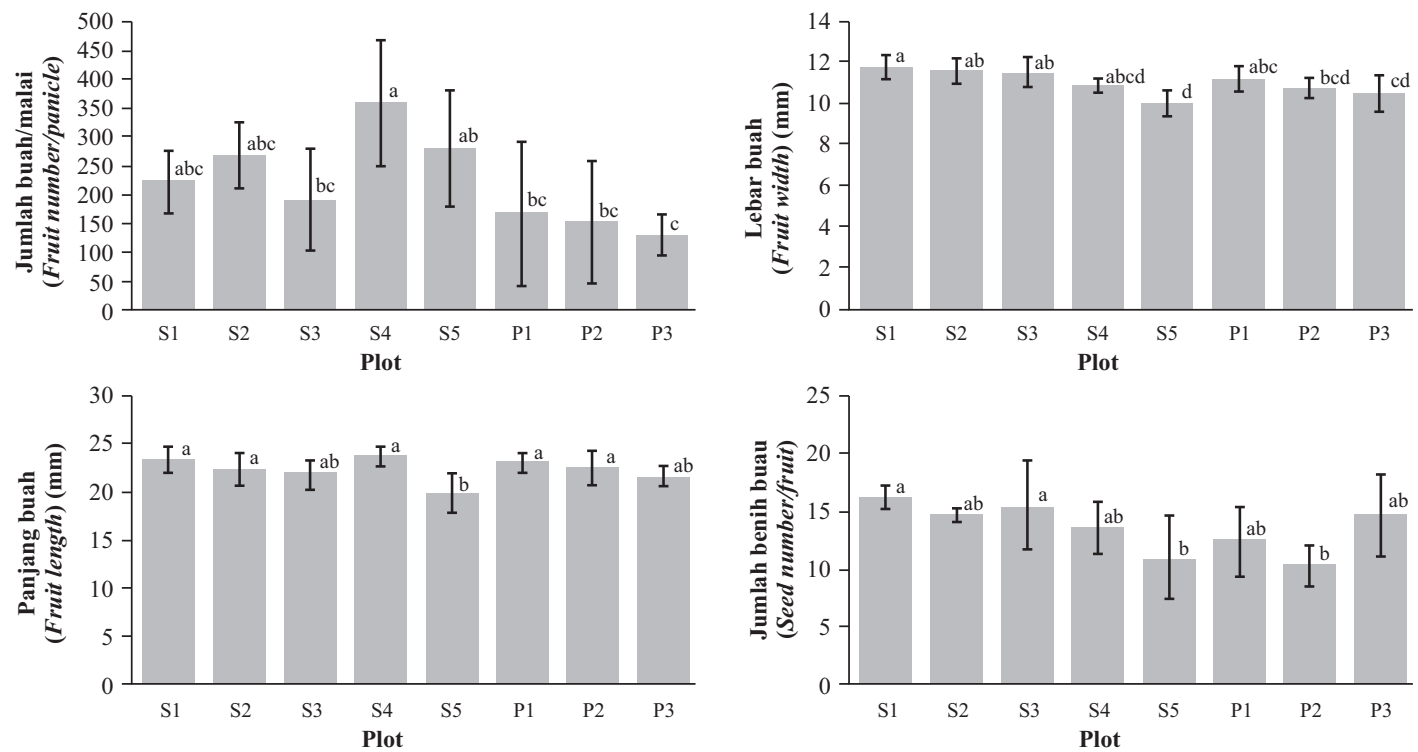

Sumber (Source): Diolah dari data lapang (Compiled and analyzed from field data)

Gambar(Figure)2. Karakteristik produksi buah dan benih di lokasi penelitian (The characteristic of fruit and seed production of observed stands)

Tabel(Table) 6. ANOVA terhadap parameter variabel produksi benih (ANOVA of seed production variables)

\begin{tabular}{lrcc}
\hline \multicolumn{1}{c}{ Parameter } & Mean Square & F & Sig. \\
\hline Jumlah malai per pohon & $1.505,210$ & 1,378 & 0,260 \\
Jumlah buah per malai & $23.471,860$ & 2,948 & 0,022 \\
Panjang buah & 5,714 & 2,623 & 0,037 \\
Diameter buah & 1,478 & 4,071 & 0,004 \\
Rasio Lebar/Panjang buah & 0,002 & 1,553 & 0,198 \\
Jumlah benih & 18,070 & 2,516 & 0,043 \\
Jumlah ovul per bunga & 13,557 & 0,588 & 0,759 \\
Daya berkecambah benih & 176,071 & 5,861 & 0,000 \\
\hline
\end{tabular}

Sumber (Source): Diolah dari data lapang (Compiled and analyzed from field data)

Ukuran buah berbeda nyata di antara plot-plot penelitian. Ukuran buah terkecil dijumpai pada pohon surian yang berada di plot S5. Panjang buah pada plot ini tidak berbeda nyata dengan plot S3 dan P3, sedangkan lebar buahnya tidak berbeda nyata dengan plot S4 dan P3. Ukuran buah, baik panjang maupun lebar, pada plot $\mathrm{S} 1$, S2, S3, S4, dan P1, tidak berbeda nyata.

\section{Korelasi antara status nutrisi daun dan produksi bunga, buah dan benih}

Variasi unsur hara makro daun yaitu N, P, K yang terjadi di atara tegakan, secara umum tidak berkorelasi dengan variabel-variabel produksi yang diamati (Tabel 7). Status unsur hara daun yang berkaitan dengan variabel produksi adalah anasir $\mathrm{K}$ dalam daun yang berkorelasi negatif dengan jumlah bunga dan status $\mathrm{P}$ pada daun yang berkorelasi negatif dengan jumlah benih.

Beberapa unsur hara mikro pada daun berkorelasi dengan beberapa variabel produksi. Jumlah malai per pohon berkorelasi positif dengan konsentrasi Ca daun tetapi tidak berkorelasi secara nyata dengan konsentrasi unsur hara makro maupun mikro lainnya. Selain berkorelasi dengan jumlah malai, $\mathrm{Ca}$ juga berkorelasi positif dengan jumlah bunga per malai. Jumlah bunga per malai juga berkorelasi dengan konsentrasi anasir Mg. Ukuran buah yang meliputi panjang buah, rasio panjang/lebar dan lebar buah tidak berkorelasi dengan semua variabel unsur hara pada daun. 
Tabel(Table) 7. Hasil analisis korelasi antara status nutrisi daun terhadap produksi benih (The result of correlation analysis between leaf nutrition and seed production variables)

\begin{tabular}{|c|c|c|c|c|c|c|c|c|}
\hline $\begin{array}{l}\text { Nutrisi daun } \\
\text { (Leaf } \\
\text { nutrition) }\end{array}$ & & $\begin{array}{c}\text { Jumlah malai } \\
\text { per } \\
\text { pohon } \\
\text { (Spikes per } \\
\text { tree) }\end{array}$ & $\begin{array}{c}\text { Jumlah } \\
\text { bunga per } \\
\text { malai } \\
\text { (Flowers } \\
\text { per spike) }\end{array}$ & $\begin{array}{c}\text { Jumlah } \\
\text { buah per } \\
\text { malai) } \\
\text { (Fruits per } \\
\text { spike) } \\
\end{array}$ & $\begin{array}{c}\text { Panjang } \\
\text { buah } \\
\text { (Fruit } \\
\text { length) }\end{array}$ & $\begin{array}{c}\text { Lebar } \\
\text { buah } \\
\text { (Fruit } \\
\text { diameter) }\end{array}$ & $\begin{array}{l}\text { Jumlah } \\
\text { benih } \\
\text { (Seeds } \\
\text { per } \\
\text { fruit) }\end{array}$ & $\begin{array}{l}\text { Berat benih } \\
\text { (Seed } \\
\text { weight })\end{array}$ \\
\hline \multirow[t]{2}{*}{$\mathrm{N}$} & Kor. & 0,051 & 0,631 & 0,365 & 0,421 & 0,153 & $-0,279$ & $-0,394$ \\
\hline & Sig. & 0,904 & 0,093 & 0,375 & 0,298 & 0,717 & 0,504 & 0,334 \\
\hline \multirow[t]{2}{*}{$\mathrm{P}$} & Kor. & 0,205 & 0,488 & $-0,633$ & $-0,174$ & $-0,462$ & $-0,772 *$ & 0,165 \\
\hline & Sig. & 0,627 & 0,22 & 0,092 & 0,68 & 0,25 & 0,025 & 0,696 \\
\hline \multirow[t]{2}{*}{ K } & Kor. & 0,436 & 0,388 & $-0,822 *$ & $-0,31$ & $-0,42$ & $-0,569$ & 0,276 \\
\hline & Sig. & 0,28 & 0,343 & 0,012 & 0,454 & 0,3 & 0,141 & 0,507 \\
\hline \multirow[t]{2}{*}{$\mathrm{Ca}$} & Kor. & $0,825^{*}$ & $0,738^{*}$ & $-0,171$ & $-0,235$ & $-0,386$ & $-0,365$ & $-0,529$ \\
\hline & Sig. & 0,012 & 0,037 & 0,686 & 0,575 & 0,345 & 0,374 & 0,177 \\
\hline \multirow[t]{2}{*}{$\mathrm{Mg}$} & Kor. & 0,451 & $0,736^{*}$ & $-0,266$ & $-0,422$ & $-0,715^{*}$ & $-0,609$ & $-0,477$ \\
\hline & Sig. & 0,262 & 0,037 & 0,524 & 0,297 & 0,046 & 0,109 & 0,232 \\
\hline \multirow[t]{2}{*}{$\mathrm{Fe}$} & Kor. & 0,508 & 0,044 & 0,014 & $-0,102$ & 0,376 & 0,672 & $-0,155$ \\
\hline & Sig. & 0,199 & 0,918 & 0,973 & 0,811 & 0,358 & 0,068 & 0,715 \\
\hline \multirow[t]{2}{*}{$\mathrm{Mn}$} & Kor. & 0,569 & 0,408 & $-0,438$ & $-0,335$ & 0,211 & $-0,122$ & 0,148 \\
\hline & Sig. & 0,141 & 0,316 & 0,278 & 0,417 & 0,617 & 0,773 & 0,727 \\
\hline \multirow[t]{2}{*}{ Corg } & Kor. & $-0,401$ & $-0,675$ & 0,584 & $-0,031$ & 0,325 & 0,438 & 0,021 \\
\hline & Sig. & 0,325 & 0,066 & 0,128 & 0,942 & 0,433 & 0,278 & 0,961 \\
\hline \multirow[t]{2}{*}{$\mathrm{Na}$} & Kor. & 0,22 & 0,512 & 0,023 & 0,323 & $-0,033$ & $-0,527$ & $-0,527$ \\
\hline & Sig. & 0,626 & 0,196 & 0,942 & 0,571 & 0,775 & 0,023 & 0,7775 \\
\hline
\end{tabular}

Sumber (Source): Diolah dari data lapang (Compiled and analyzed from field data)

Keterangan $($ Remarks $): *=$ Ada perbedaan nyata antar plot pada tingkat 0,$05 ;$ Kor $=$ koefisien korelasi; Sig $=$ nilai $\mathrm{p} .(*=$ There are different significantly among plot at the 0.05 level; Kor $=$ Corellation coefficient; $\operatorname{Sig}=p$-Value $)$.

\section{B. Pembahasan}

Plot-plot yang berada di Desa Padasari memiliki $\mathrm{pH}$ yang lebih rendah dan kesuburan yang lebih tinggi dari plot-plot di Desa Sukajadi karena plot-plot ini berada pada area dengan jenis tanah aluvial yang subur, sedangkan plot yang berada lokasi di Desa Sukajadi berada pada lokasi dengan jenis tanah Latosol dengan kandungan liat tinggi, KTK rendah, dan $\mathrm{pH}$ asam. Plot S1, S2 dan S3 memiliki kesuburan tanah sangat mirip karena ketiga plot berada pada jenis tanah yang sama dan dikelola dengan pola tanam yang mirip yaitu pepohonan monokultur dengan tanaman semusim. Plot S4 memiliki kandungan nutrisi yang lebih baik, terutama konsentrasi C dan $\mathrm{N}$, dibanding dengan plot lainnya yang berada pada area dengan jenis tanah yang sama, diduga karena komposisi jenis pepohonan pada plot ini lebih beragam yang berisi beberapa jenis tanaman legum yang mampu mengikat $\mathrm{N}$ udara. Semakin beragam jenis pohon menyebabkan terbentuknya stratifikasi fisik dan kimiawi akar sehingga kompetisi penyerapan unsur hara menjadi lebih rendah (Forrester et al., 2006). Selain itu pada Plot S4 kegiatan tumpangsari dilakukan lebih intensif sehingga input $\mathrm{N}$ dari pemupukan relatif lebih tinggi. Konsentrasi $\mathrm{C}$ organik yang lebih tinggi pada Plot S4 diduga karena tegakan campuran memiliki produktifitas serasah yang lebih tinggi daripada tegakan monokultur. Hal ini sejalan dengan hasil penelitian Forrester et al. (2005).

Secara teoritis konsentrasi unsur hara pada daun dipengaruhi oleh konsentrasi hara bersangkutan di dalam tanah (Kozlowski \& Pallardy, 1979), namun dalam penelitian ini berdasarkan uji korelasi ternyata konsentrasi unsur hara tanah tidak berkorelasi secara nyata dengan konsentrasi unsur hara daun. Hal ini diduga karena konsen-trasi hara dalam daun menurut Wu et al. (2007) tidak hanya ditentukan oleh status nutrisi tanah tetapi juga oleh faktor lingkungan lainnya, misal-nya ketinggian tempat, posisi topografi, kemiringan, tipe vegetasi, dan status nutrisi tanah. Dengan demikian, pada penelitian ini perbedaan kondisi fisik pohon surian, perbedaan pola pengelolaan, perbedaan komposisi dan struktur tegakan, di delapan plot penelitian berpengaruh terhadap efektifitas penyerapan unsur hara, sehingga kenaikan atau penurunan konsentrasi unsur hara tanah pada plot tertentu dibanding plot lain tidak selalu diikuti oleh kenaikan atau penurunan unsur hara bersangkutan di dalam daun. 
Menurut Kelly et al. (2007) pengaruh tapak terhadap pembungaan yang sangat signifikan adalah akibat dari perbedaan kondisi iklim dan tanah, misalnya perbedaan kesuburan tanah (Kelly et al., 2007). Wani et al. (2010) juga menyatakan bahwa nutrisi tanah menentukan persentase bunga sempurna, pemasakan bunga, dan viabilitas pollen. Rendahnya status nutrisi pada tanaman dapat menyebabkan terbentuknya pistil yang cacat, sehingga keseimbangan suplai nutrisi selalu diperlukan untuk menciptakan produksi buah yang optimum. Pada penelitian surian ini, hasil pengamatan menunjukkan bahwa konsentrasi kimia yang berkorelasi dengan pembungaan adalah $\mathrm{Ca}$ dan $\mathrm{Mg}$. Jumlah malai per pohon dan jumlah bunga per malai meningkat sejalan dengan meningkatnya konsentrasi $\mathrm{Ca}$ pada daun. Hal ini sejalan dengan Tisdale (1985) dalam Rosmarkam \& Yuwono (2002) bahwa Kalsium memiliki peranan yang erat dengan pembentukan jaringan apikal dan pembentukan bunga. Namun demikian, hasil penelitian menunjukkan bahwa produksi malai ini tidak berbeda nyata antar plot pengamatan. Konsentrasi $\mathrm{Mg}$ daun berkorelasi positif secara nyata dengan produksi bunga per malai, dan berkorelasi positif lemah dengan produksi malai. Menurut Copeland \& McDonald (1936) status nutrisi menjadi penting ketika pembentukan bagian-bagian bunga tergantung pada ketersediaan bahan makanan dan translokasinya, sedangkan menurut Gardner et al. (1939) unsur $\mathrm{Mg}$ dan $\mathrm{Ca}$ berperan dalam transportasi karbohidrat dan pemanfaatannya. Dalam penelitian ini kaitan $\mathrm{Ca}$ dan $\mathrm{Mg}$ dengan produksi bunga diduga berkaitan dengan translokasi bahan makanan dari daun ke tunas reproduktif atau ke bunga.

Pada penelitian surian ini konsentrasi $\mathrm{N}$ pada daun tidak berpengaruh nyata terhadap produksi bunga. Hasil ini berbeda dengan beberapa penelitian lain yang mengungkapkan adanya pengaruh $\mathrm{N}$ terhadap pembungaan, misalnya penelitian Gray \& Garrett (1999) yang menunjukkan bahwa penambahan pupuk $\mathrm{N}$, memiliki efek positif pada jumlah bunga betina yang terbentuk pada pohon Missouri black walnut. Hal ini terjadi karena konsentrasi N pada daun $T$. sinensis antar plot penelitian tidak berbeda nyata dan konsentrasi pada semua lokasi yang berkisar antara $2,37 \%$ hingga $3,16 \%$, diduga konsenetasi ini telah mencukupi untuk pembentukan bunga sempurna, sehingga variasi tingkat $\mathrm{N}$ tidak menjadi faktor pembatas terhadap reproduksi bunga. Hal ini dimungkinkan karena pada olive (Olea europaea L.) kenaikan dari konsentrasi $\mathrm{N}$ daun yang berawal dari tingkat $0,8 \%$ akan diikuti secara cepat terhadap peningkatan intensitas pembungaan, persentase bunga sempurna, dan jumlah bunga per malai, kemudian setelah melewati tingkat $1,56 \%$ perbedaan konsentrasi $\mathrm{N}$ pengaruhnya melemah (Erel et al., 2013).

Anasir P mudah diredistribusikan dari satu organ ke organ lain. P hilang dari daun-daun tua, mengumpul pada daun-daun muda dan pada bunga dan benih yang sedang berkembang (Salisbury \& Ross, 1992). Pada penelitian surian ini, variasi konsentrasi $\mathrm{P}$ daun pada semua lokasi yang berkisar antara $0,13 \%$ hingga $0,22 \%$, termasuk tinggi dibandingkan pada pohon lain. Pada pohon oak (Quercus ilex L.) pada penelitian Marcos et al., (2007) konsentrasi P tertinggi sekitar $0,18 \%$ dan pohon olive (Olea europaea L.) konsentrasi $\mathrm{P}$ berkisar 0,06-0,18\%, pada Carob berkisar antara 0,07-0,12\% (Correia, 2002). Pada Pinus radiata dan C. lusitanica di bawah 0,18 (Davis et al., 2007). Hasil penelitian menunjukkan bahwa konsentrasi P pada daun surian tidak berpengaruh nyata terhadap pembungaan. Hasil ini berbeda dengan hasil peneilitian terhadap pohon Ipomoea wolcottiana Rose, konsentrasi P tanah berdampak positif, meskipun lemah untuk produksi bunga (Tabla \& Bullock, 2006). Diduga konsentrasi $\mathrm{P}$ daun surian pada tapak penelitian telah cukup untuk produksi bunga karena menurut Kozlowski \& Pallardy (1979) defisiensi $\mathrm{P}$ akan mengakibatkan penurunan produksi bunga dan buah. Hal ini sejalan dengan penelitian pada olive di mana intensitas pembungaan tidaklah dipengaruhi oleh P sepanjang kekurangan berat $\mathrm{P}$ bisa dihindarkan yaitu $\mathrm{P}$ daun di atas $0,09 \%$. Sedangkan jumlah bunga untuk setiap malai cenderung meningkat dengan meningkatnya P. Namun pada konsentrasi di atas batas sekitar $0,13 \%$, peningkatan konsentrasi $\mathrm{P}$ daun tidak menunjukkan pengaruh positif terhadap produksi bunga (Erel et al., 2013).

Secara umum produksi buah dan benih tertinggi dijumpai pada tegakan dengan pola tanam pohon surian monokultur dengan tum-pangsari tanaman semusim (plot S1 dan S2), dan pola tanam kebun campur dengan tumpangsari tanaman semusim (plot S4). Tingginya produksi buah dan benih ini diduga tidak berkaitan langsung dengan perbedaan unsur hara tanah, karena hampir semua unsur hara tidak berkorelasi dengan produksi buah dan benih, kecuali unsur hara $\mathrm{P}$ yang berkorelasi negatif terhadap produksi buah dan anasir hara $\mathrm{K}$ yang berkorelasi negatif terhadap produksi benih.

Kozlowski \& Pallardy (1979) mengemukakan bahwa pembuahan berkurang karena defi- 
siensi P. Pada penelitian surian konsentrasi $\mathrm{P}$ daun di antara beberapa plot penelitian berbeda nyata. Konsentrasi $\mathrm{P}$ berkorelasi negatif secara nyata terhadap jumlah benih dan tidak menunjukkan korelasi yang nyata terhadap produksi buah. Plot $\mathrm{P} 1$ dan $\mathrm{P} 3$ yang memiliki kandungan anasir $\mathrm{P}$ tinggi, menghasilkan buah per malai yang rendah, dan produksi benih per buah yang tinggi. Hasil ini sejalan dengan penelitian (Correia et al., 2002) bahwa konsentrasi $P$ daun berkorelasi negatif dengan produksi buah pada pohon carob (Ceratonia siliqua L.), dan hasil penelitian pada produksi buah Bertholletia excelsa (Kainer et al., 2007). Hasil penelitian pada surian ini berbeda dengan penelitian yang menyatakan bahwa $\mathrm{P}$ tanah berdampak positif terhadap produksi buah misalnya pada pohon Ipomoea wolcottiana Rose (Tabla \& Bullock, 2006), pohon oak (Quercus ilex L.). (Marcos et al., 2007), dan pohon olive (Olea europaea L.) (Erel et al., 2013). Pada penelitian ini peningkatan konsentrasi P menyebabkan penurunan produksi buah dan benih diduga karena pada plot-plot tertentu (P1 dan P2) memiliki konsentrasi P yang terlampau tinggi sehingga menyebabkan pengaruh negatif. Tingginya konsentrasi $\mathrm{P}$ daun di plot-plot ini diduga berkaitan dengan konsentrasi $\mathrm{P}$ dalam tanah di kedua plot tersebut yang juga sangat tinggi.

Pada penelitian ini konsentrasi anasir $\mathrm{K}$ di dalam daun antar plot bervariasi antara 0,58$1,8 \%$. Konsentrasi $\mathrm{K}$ pada pohon sampel yang dijumpai pada Padasari 3 yang berkisar antara $1,7-1,86 \%$, termasuk sangat tinggi dibandingkan dengan hasil penelitan lain. Pada carob konsentrasi K berkisar 0,5-1,5 (Correia et al., 2002). Pada pinus di bawah 0,18 dan pada C. lusitanica di bawah 1,5 (Davis et al., 2007). Hasil penelitian terhadap surian menunjukkan bahwa hanya anasir $\mathrm{K}$ yang berkorelasi negatif yang signifikan terhadap produksi buah per malai. Kandungan anasir $\mathrm{K}$ dalam daun yang tertinggi dijumpai di S4 dan terendah pada P2 sejalan dengana produksi benih pada plot S4 yang tinggi dan P2 yang rendah (Gambar 2). Diduga hal ini terkait dengan perbedaan yang nyata dalam konsentrasi $\mathrm{K}$ daun antar plot penelitian. Hasil ini berbeda dengan penelitian pada olive yang menunjukkan bahwa tingkat $\mathrm{K}$ tidak memberi pengaruh penting terhadap pembungaan, pembentukan buah (fruit set) atau keseluruhan produktifitas (Erel et al., 2013). Unsur K memang tidak berpengaruh secara langsung terhadap produksi buah, tetapi berperan dalam pencegahan kerontokan buah karena $\mathrm{K}$ dalam tubuh tanaman memacu penebalan dinding sel dan kekuatan tangkai (Poerwowi- dodo,1993; Foth, 1978). Hasil penelitian ini belum diketahui penyebab dari korelasi negatif dari konsentrasi K. Mungkin karena rendahnya pembentukan buah disebabkan oleh faktor-faktor lingkungan biotik lainnya seperti keterbatasan serangga penyerbuk atau tingginya inbreeding atau selfing.

Pada penelitian ini $\mathrm{N}$ daun tidak berkorelasi secara nyata terhadap semua parameter produksi. $\mathrm{Hal}$ ini terjadi karena variasi konsentrasi $\mathrm{N}$ daun antar plot penelitian rendah dan tidak berbeda nyata. Peningkatan produksi diduga bisa terjadi jika dilakukan penambahan anasir $\mathrm{N}$ secara signifikan melalui pemupukan, sebagaimana hasil penelitian Pramono et al. (2011) yang menunjukkan bahwa pemberian pupuk urea terhadap pohon surian di Desa Sukajadi mampu meningkatkan produksi buah. Pengaruh pemupukan terhadap peningkatan produksi buah juga dilaporkan oleh Gray \& Garrett (1999) pada black walnut, penelitian Marcos et al. (2007) dan pada pohon oak (Quercus ilex L.).

Pada penelitian ini konsentrasi $\mathrm{Fe}$ daun tidak berbeda nyata antar plot penelitian. Konsentrasi Fe pada daun tidak berpengaruh langsung terhadap produksi benih karena besi termasuk anasir hara yang tidak mobil sehingga tidak ditranslokasikan dari daun ke organ tanaman lainnya (Poerwowidodo, 1993).

Pada penelitian ini konsentrasi Kalsium (Ca) pada daun surian tidak berbeda nyata antar lokasi penelitian, dan konsentrasi $\mathrm{Ca}$ juga tidak berkorelasi secara nyata terhadap ukuran dan produksi buah dan benih surian. Hasil ini sejalan dengan penelitian pada pohon carob, konsentrasi $\mathrm{Ca}$ tidak berkorelasi nyata terhadap (Correia et al., 2002).

Pada penelitian ini konsentrasi Mg daun berbeda nyata di antara beberapa plot, namun konsentrasi unsur hara ini tidak berpengaruh nyata terhadap produksi buah dan benih. Hasil penelitian pada tegakan surian ini berbeda dengan penelitian pada carob, $\mathrm{Mg}$ tidak berkorelasi nyata terhadap produksi (Correia et al., 2002). Hal ini menunjukkan bahwa kisaran konsentrasi $\mathrm{Mg}$ antara $0,10-0,16 \%$ pada plot-plot penelitian belum berpengaruh terhadap perbedaan produksi.

Pada penelitian ini Mn tidak berbeda nyata antar plot penelitian dan Mn dalam daun berkorelasi negatif lemah terhadap jumlah buah dan berkorelasi positif lemah dengan jumlah malai, jumlah bunga dan rasio L/P buah. Hal ini menunjukkan bahwa peningkatan Mn dapat berperan dalam meningkatan produksi benih melalui peningkatan jumlah jumlah malai dan jumlah 
bunga. Sedangkan pembentukan buah diduga lebih banyak ditentukan oleh tingkat keberhasilan penyerbukan. Pengaruh positif dari konsentrasi Mn terhadap produksi buah ini sejalan dengan penelitian pada pohon Carob (Correia et al., 2002). Konsentrasi C org dalam tanah pada penelitian tidak berbeda nyata antar plot penelitian dan tidak berkorelasi secara nyata dengan satupun variabel produksi.

\section{KESIMPULAN DAN SARAN}

Terdapat perbedaan di antara plot penelitian dalam hal konsentrasi unsur hara tertentu di dalam daun, produksi buah, dan produksi benih surian. Variasi status beberapa unsur hara $(\mathrm{N}, \mathrm{Fe}$, $\mathrm{Mn}, \mathrm{C}$ organik dan $\mathrm{Na}$ ) pada daun surian di lokasi penelitian tidak menunjukkan korelasi terhadap beberapa parameter produksi benih sehingga tidak menjadi faktor pembatas bagi produksi. Status nutrisi $\mathrm{N}$ pada daun dari pola tanam surian tidak berpengaruh nyata terhadap semua parameter produksi benih. Konsentrasi unsur hara $\mathrm{Ca}$, $\mathrm{Fe}, \mathrm{Mn}$ dan Na pada daun juga tidak menunjukkan perbedaan yang nyata antar pola tanam surian. Unsur yang memiliki variasi yang nyata antar pola tanam adalah $\mathrm{P}, \mathrm{K}, \mathrm{Mg}$, dan $\mathrm{C}$ organik. $\mathrm{Ca}$ dan $\mathrm{Mg}$ berpengaruh positif terhadap jumlah bunga per malai. Ca berpengaruh positif terhadap jumlah malai per pohon. Konsentrasi K berkorelasi negatif dengan produksi buah dan P yang berkorelasi negatif terhadap produksi benih. Produksi buah dan benih tertinggi dijumpai pada tegakan dengan pola tanam surian monokultur dengan tumpangsari tanaman semusim, dan pola tanam kebun campur dengan tumpangsari tanaman semusim. Pembangunan sumber benih surian dapat diterapkan dengan pola tanam monokultur atau kebun campuran dengan menerapkan sistem tumpangsari dengan tanaman semusim

\section{UCAPAN TERIMA KASIH}

Ucapan terima kasih disampaikan kepada Bapak Bambang dan Bapak Yana Sudaryana (karyawan Unit Pelaksana Teknis Daerah (UPTD) Kehutanan di Wado), Bapak Entis (Ketua Kelompok Tani di Desa Padasari) serta Bapak Hasan Royani (teknisi di Balai Penelitian Teknologi Perbenihan Tanaman Hutan) atas bantuan teknis selama pengamatan di lapangan. Terima kasih juga disampaikan kepada Bapak
Herman Suherman dan teknisi di Laboratorium Balai Penelitian Teknologi Perbenihan Tanaman Hutan untuk bantuannya selama pengamatan di Laboratorium.

\section{DAFTAR PUSTAKA}

Balai Penelitian Tanah Badan Penelitian dan Pengembangan Pertanian Departemen Pertanian. (2005). Petunjuk teknis analisis kimia tanah, tanaman, air, dan pupuk. Akses tanggal 24 Oktober 2013, dari http://balittanah.litbang. deptan.go.id/dokumentasi/juknis/juknis_ kimia.pdf.

Chifflot, V., Bertoni, G., Cabanettes, A., \& Gavaland, A. (2006). Beneficial effects of intercropping on the growth and nitrogen status of young wild cherry and hybrid walnut trees. Agrofor. Syst., 66, 13-21.

Copeland, L.O., \& McDonald, M.B. (1936). Principles of seed science and technology. $4^{\text {th }}$ ed. London: Kluwer Academic Publishers.

Correia, P.D., Anastacio, I., Candeias, M.F., \& Martins-Loucao, M.A. (2002). Nutritional diagnosis in carob-tree: Relationships between yield and leaf mineral concentration. Crop Science., 42, 1577-1583.

Davis, M.R., Coker, G., Parfitt, R.L., Simcock, R., Clinton, P.W., Garrett, L.G., \& Watt, M.S. (2007). Relationships between soil and foliar nutrients in young densely planted mini-plots of Pinus radiata and Cupressus lusitanica. Forest Ecology and Management, 240, $122-130$.

De Foresta, H., \& Michon, G. (2000). Agroforestri Indonesia: Beda sistem beda pendekatan. Dalam Ketika kebun berupa hutan - Agroforest khas Indonesia - Sebuah sumbangan masyarakat. De Foresta, H.; Kusworo, A; Michon, G; Djatmiko, W.W. ed. International Centre For Research In Agroforestry. Bogor.

Erel, R., Yermiyahu, U., Opstal, J.V., Ben-Gal, A., Schwartz, A., \& Dag, A. (2013). The importance of olive (Olea europaea L.) tree nutritional statuson its productivity. Scientia Horticulturae, $159,8-18$

Forrester, D.I., Bauhus, J., \& Cowie, A.L. (2005). Nutrient cycling in a mixed-species plantation of Eucalyptus globulus and Acacia mearnsii. Can. J. For. Res., 35, 2942-2950.

Forrester, D.I., Bauhus, J., Cowie, A.L., Vanclay, J.K. (2006). Mixed-species plantations of Eucalyptus with nitrogen-fixing trees: A review. Forest Ecology and Management, 233, 211-230. 
Foth, H.D. 1978. Fundamentals of Soil Science. Sixth Edition. Toronto: John Wiley \& Sons.

Ganatsas, P., Tsakaldimi, M., \& Thanos, C. (2008). Seed and cone diversity and seed germination of Pinus pinea in Strofylia Site of the Natura 2000 Network. Biodivers Conserv., 17, 24272439.

Gardner. V.R., Bradford, F.C., \& Hooker, H.D. (1939). The fundamentals of fruit production. London: McGraw-Hill Book Company, Inc.

Gray, D. and H.E.G. Garrett. (1999). Nitrogen fertilization and aspects of fruit yield in a Missouri black walnut alley cropping practice. Agroforestry Systems, 44, 333-344.

Jones, F.A., \& Comita, L.S. (2008). Neighbourhood density and genetic relatedness interact to determine fruit set and abortion rates in a continuous tropical tree population. Proc. $R$. Soc. B., 275, 2759-2767.

Kainer, K.A., Wadt, L.H.O., \& Staudhammer, C.L. (2007). Explaining variation in Brazil nut fruit production. Forest Ecology and Management, 250, 244-255.

Kelly, B.A., Fleury, S.G., Bouvet, J.M. (2007). Impact of agroforestry practices on the flowering phenology of Vitellaria paradoxa in parklands in southern Mali. Agroforest Syst., 71, 67-75.

Kozlowski, T.T. (1971). Growth and development of trees. Vol II. Cambial growth, root growt and reproductive growth. New York and London: Academic Press.

Kozlowski, T.T., \& Pallardy, S.G. (1979). Physiology of woody plants. 2nd ed. Academic Press.

Kuswanto, H. (1996). Dasar-dasar teknologi, produksi dan sertifikasi benih. Yogyakarta: Penerbit ANDI.

Marcos, G.M., Obrador, J.J., Garc1'a, E., \& Cubera, E. (2007). Driving competitive and facilitative interactions in oak dehesas through management practices. Agroforest Syst., 70, 25-40.

Owens, J.N. (1995). Constraints to seed production: temperate and tropical forest trees. Tree Physiology, 15, 477-484.

Peba, L.S., \& Tabla, V.P. (2007). Fenologi dan penyerbukan Manilkara zapota di hutan dan pekarangan. Forest Ecol. Manage., 248, 136142.

Poerwowidodo. (1993). Telaah kesuburan tanah. Bandung: Penerbit Angkasa.

Pramono, A.A., Danu, Abidin, Z., Royani, H., \& Suartha, P.G.P. (2009). Zona ekologi sebaran populasi tanaman hutan untuk pengembangan sumber benih suren di Jawa. Laporan Hasil Penelitian Sumber Dana Dipa BPTP Bogor Tahun 2009. Bogor: Balai Penelitian Teknologi
Perbenihan Bogor, Badan Penelitian dan Pengembangan Kehutanan. Departemen Kehutanan. Tidak dipublikasikan.

Pramono, A.A., Aminah, A., Putri, K.P., Muharam, A., \& Royani, H. (2011). Teknik peningkatan produksi benih tanaman hutan penghasil kayu pertukangan jenis nyawai (Ficus variegata), jelutung rawa (Dyera lowii) dan suren (Toona sinensis). Laporan Hasil Penelitian Tahun 2011. Bogor: Balai Penelitian Teknologi Perbenihan Tanaman Hutan. Tidak dipublikasikan.

Renison, D., Hensen, I., Cingolani, A.M. (2004). Anthropogenic soil degradation affects seed viability in Polylepis australis mountain forests of central Argentina. Forest Ecology and Management, 196, 327-333.

Racskó, J., Leite, G.B., Petri, J.L., Zhongfu, S., Wang, Y., Szabó, Z., Soltész M., \& Nyéki, J. (2007). Fruit drop: The role of inner agents and environmental factors in the drop of flowers and fruits. International Journal of Horticultural Science, 13 (3), 13-23.

Rosmarkam, A.Q., \& Yuwono, N.W. (2002). Ilmu kesuburan tanah. Yogyakarta: Penerbit Kanisius.

Salisbury, F.B., \& Ross, C.W. (1992). Plant physiology. 4th ed. California: Wadsworth Publishing Co.

Sardjono, M.A., Djogo, T., Arifin, H.S., \& Wijayanto, N. (2003). Klasifikasi dan pola kombinasi komponen agroforestri. Bogor, Indonesia: World Agroforestry Centre (ICRAF).

Tabla, V.P., \& Bullock, S.H. (2006). Exploring the limiting causes of fruit production in the tropical tree Ipomoea wolcottiana Rose (Convolvulaceae). Plant Ecology, 166, 107115 .

Van Noordwijk, M., Roshetko, J.M., Murniati, Angeles, M.D., Suyanto, Fay, C., \& Tomich, T.P. (2003). Agroforestry is a form of sustainable forest management: Lessons from South East Asia. For delivery at: UNFF Intersessional Experts Meeting on the Role of Planted Forests in Sustainable Forest Management Conference, 24-28 March 2003, Wellington, New Zealand.

Wani, I.A., Bhat, M.Y., Lone, A.A., \& Mir, M.Y. (2010). Unfruitfulness in fruit crops: Causes and remedies. African Journal of Agricultural Research, 5(25), 3581-3589.

Wu, C.C., Tsui, C.C., Hseih, C.F., Asio, V.B., \& Chen, Z.S. (2007). Mineral nutrient status of tree species in relation to environmental factors in the subtropical rain forest of Taiwan. For. Ecol. Manage., 239, 81-91. 